MaPan : Jurnal Matematika dan Pembelajaran

p-ISSN: 2354-6883 ; e-ISSN: 2581-172X

Volume 7 No 1, June 2019 (99-111)

DOI: https://doi.org/10.24252/mapan.2019v7n1a8

\title{
THE DEVELOPMENT OF CONCEPTUAL-CONFLICT-BASED LEARNING DEVICE IN MATHEMATICAL PROBLEM SOLVING
}

\author{
Andi Ika Prasasti Abrar1), Andi Dian Angriani'2), Andi Halimah ${ }^{3)}$, Fitriani Nur ${ }^{4}$ \\ 1,2,3,4Fakultas Tarbiyah dan Keguruan UIN Alauddin Makassar \\ 1,2,3,4Kampus II: Jalan H.M. Yasin Limpo Nomor 36 Samata-gowa \\ E-mail: andi.ika.prasasti@uin-alauddin.ac.id1), dian.angriani@uin-alauddin.ac.id2), \\ andi.halimah@uin-alauddin.ac.id ${ }^{3}$, $\underline{\text { fitriani.nur@uin-alauddin.ac.id }}^{4}$
}

Submitted: 02-05-2019, Revised: 13-06-2019, Accepted: 14-06-2019

\begin{abstract}
:
This study aimed to develop conceptual-conflict-based learning device in mathematical problem solving on the subject of equations in three variables systems in the class $\mathrm{X}$ at MIA MAN 1 Makassar which was valid, practical and effective. The type of this study was research and development which consisted of: Lesson Plans, Student Book, Student Worksheet, and Learning Outcomes Test. The developmental model used was 4D model which consisted of difining, designing, developing and disseminating. The result of this study obtained that learning device was valid criteria based on the assessment from two validators. While the result of the limited trial showed the learning device was practical, but there were still several suggestions from observers that need to be considered to improve the practicality of the device. It was also effective which was proved by the completeness of learning outcomes that has been achieved, students' activity was as expected, the ability of teachers to manage the learning was in a high category and the students' responses was in a positive category.
\end{abstract}

Keywords: Conseptual-Conflict-Based Learning, Problem Solving

\begin{abstract}
Abstrak:
Penelitian ini bertujuan menghasilkan perangkat pembelajaran matematika berbasis konflik konseptual dalam pemecahan masalah pada pokok bahasan sistem persamaan linear tiga variabel kelas X MIA MAN 1 Makassar yang valid, praktis dan efektif. Jenis penelitian ini adalah penelitian dan pengembangan yang terdiri atas: Rencana Pelaksanaan Pembelajaran, Buku Siswa, Lembar Kerja Peserta Didik, dan Tes Hasil Belajar. Model pengembangan yang digunakan adalah model 4D yang terdiri dari tahapan perancangan, pendefinisian, pengembangan dan penyebaran. Hasil penelitian yang diperoleh adalah perangkat pembelajaran memenuhi kriteria valid berdasarkan penilaian oleh dua orang validator. Sedangkan hasil yang diperoleh pada uji coba terbatas, yaitu perangkat pembelajaran sudah praktis, tetapi masih ada beberapa saran pengamat yang perlu diperhatikan untuk meningkatkan kepraktisan perangkat. Perangkat pembelajaran sudah efektif dilihat dari ketuntasan hasil belajar yang telah tercapai, aktivitas siswa sudah sesuai yang diharapkan, kemampuan guru mengelola pembelajaran sudah dalam kategori tinggi dan respon siswa sudah dalam kategori positif.
\end{abstract}


Kata Kunci: Perangkat Pembelajaran Konflik Konseptual, Pemecahan Masalah

How to Cite: Abrar, A. I. P., Angriani, A. D., Halimah, A., \& Nur, F. (2019). The development of conseptual-conflict-based learning device in mathematical problem solving. MaPan : Jurnal Matematika dan Pembelajaran, 7(1), 99-111.

\section{INTRODUCTION}

Today the development of science, technology and art is increasingly rapid and has ushered humanity into an era of global competition in various fields of life. The main step that must be prepared is the availability of strong human resources that is strong, sturdy, time-tested and has reliable capabilities in their fields. For this reason, in the world of national education, it is demanded to create teachers as competent and educational learning facilitators. Competent and professional teachers who are also inspiring are referred to learning teachers as proclaimed by the Indonesian government in an effort to improve the quality of education.

Permendiknas Number 70 of 2013 (Kemendiknas, 2013) explain that the 2013 Curriculum aims to prepare Indonesian people to have the ability to live as individuals and citizens who are faithful, productive, creative, innovative, and affective and able to contribute to community life, nationhood, and world civilization. In addition, Lerner (in Abdurrahman, 2009) suggests that the curriculum in the field of mathematics should include three elements, (1) concepts, (2) skills, and (3) problem solving.

Therefore, the urgent ability achieved by students from the results of the learning process in schools is mastery of concepts, skills, and problem solving skills. This ability is a competency that is mastery of knowledge (Abrar, 2016). Problem solving is a process of accepting problems as a challenge to be solved and is a common goal in teaching mathematics (Angriani \& Bernard, Nur, 2016). Furthermore, Cooney (Sutrisman \& Tambunan., 1987) says that problem solving is the process of accepting problems and trying to solve them. While Polya (1973) defines problem solving as an effort to find a way out of a difficulty in achieving a goal that is not immediately achievable. It is very important to study mathematics specifically about solving mathematical problems in life (Lahinda \& Jailani., 2015) . Thus, problem solving is the main goal of all mathematics learning and is an integral part of all mathematical activities.

One of alternative learning strategies that can be designed to strengthen problem-solving skills for students while at the same time providing an 
accompanying impact on the character that can prevent violence due to unresolved social conflict among students is a conceptual conflict strategy based on cognitive conflict theory (Liang, 2016). This strategy can be applied in problem-based learning by applying cognitive conflict strategies called the Conceptual Conflict Model in Mathematical Problem Solving.

The Conceptual Conflict Model in Mathematical Problem Solving model in the study from Asdar (2015) is based on cognitive conflict theory developed by Piaget (1985) as a strategy in learning. Cognitive conflict strategy is an alternative that can be taken by confusing the understanding of the children have with a new idea or information that is relevant in a different perspective. The purpose of giving this conflict strategy is to strengthen the understanding of the initial concept that is owned if the conflict experienced is successfully resolved under conditions of mental balance.

Sela \& Zaslavsky (2007) describe their opinions on cognitive conflict which say cognitive conflict results in a state of disequilibrium - a Piagetian term meaning lack of mental balance. It is essential to the occurrence of what Piaget termed 'true learning', that is the acquisition and modification of cognitive structures and Lee, Gyoungho (2003) describe that cognitive conflict is defined as a conflict between cognitive structure (i.e., an organized knowledge structure in the brain) and environment (i.e. a experiment, demonstration, peer's opinion, book, or something like that), or a conflict between conception in cognitive structure.

Based on the limitations of cognitive conflict stated above the limits of cognitive conflict used in this study is a conflict in the mind of someone who has understandings of a concept or its application that does not integrate with each other. Asdar (2012) says that the conflict in mind will strengthen conceptual understanding in solving mathematical problems.

Overcoming and resolving a conflict is not a simple matter, it depends on the willingness and openness of the disputing parties to resolve the conflict, the severity of the weight or level of the conflict (Wahyuni, 2017). Therefore, familiarizing students in conflict situations is a necessity accompanied by the formation of character values that leads to the discovery of solutions to conflict. Dealing with conflict, there are five actions we can take, namely competing, avoiding conflict, accommodation, compromising, and collaborating. These five actions can be accommodated in conflict learning strategies

The problem in the MAN 1 Makassar school is that most students only memorize formulas to solve problems. In solving questions with many formulas most students also have not been able to finish well. This happens because 
students assume that mathematics is a subject that has many formulas, no concepts. This indicates that the ability of students to concepts, principles and mathematical skills is still very low, so it is necessary to have devices that can foster the creative attitude of students, one of them is a problem-based learning device.

The purpose of this article is to develop conteptual-conflict-based learning device in mathematical problem solving (valid, practical, and effective), which includes: (1) Lesson Plan, (2) Student book, (3) Student Worksheet, and (4) Learning Outcome Test at the MAN 1 Makassar school.

\section{RESEARCH METHODS}

This research includes the type of development research. The research design used in connection with the objectives of the development research mentioned above is the $4 \mathrm{D}$ model of Tiangarajan. The subjects of this study were students of Madrasah Aliyah Negeri 1 Makassar in the academic year $2017 / 2018$. There are two components that will be developed in this development research, namely learning devices and instruments that will be used to assess the quality of learning devices. The device development model used in this study refers to the development of four D Models (4-D models) consisting of four stages, namely define, design, develop and disseminate, as stated by Thiagarajan. 


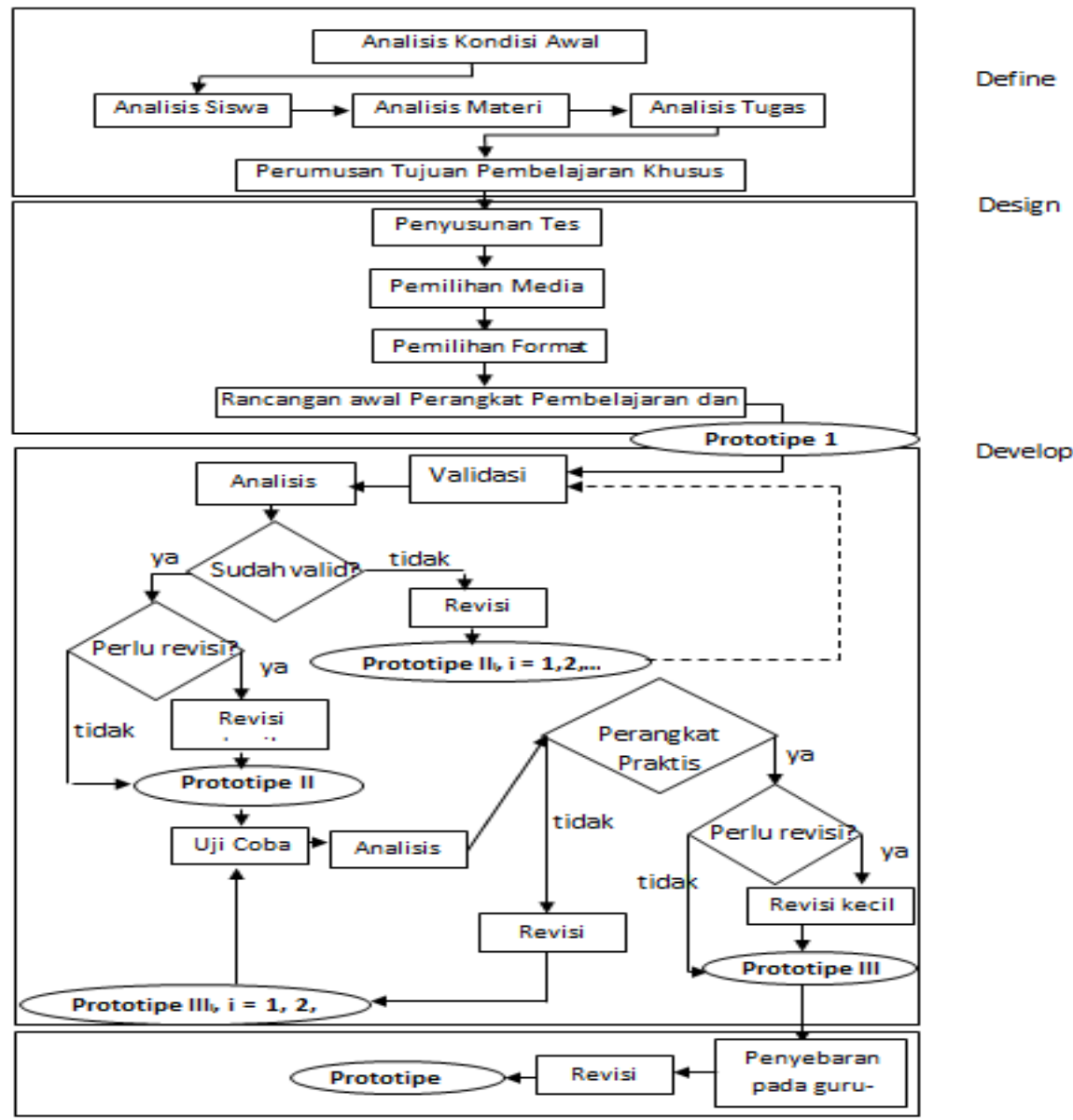

Picture 1. Research Design

\section{RESULT AND DISCUSSION}

\section{Result}

The description of the development stage in this study is as follows: a. Defining Phase (Define)

At this defining stage a check and definition of the conditions for developing a learning device based on a model of conceptual conflict have been carried out in solving mathematical problems. At this stage also carried out literature studies, relevant research studies, and observations to target schools which include: (1) preliminary analysis, (2) analysis of students, (3) material analysis, (4) task analysis, (5) specification of learning objectives.

b. Design Stage (Design)

The results of the design stage include several design activities, namely: 1) Draft of Lesson Plan

The format of the lesson plan developed in the draft lesson plan is based on the 2013 curriculum consisting of several components, namely core competencies, 
basic competencies, indicators of achievement of competencies, learning objectives, learning methods, learning media, learning resources, and learning activities.

2) Student Book

Designing student books with material systems of three-variable linear equations refers to the basic competencies of a three-variable linear equation system. Student books are prepared based on the mathematics curriculum that applies in accordance with the level of education, namely high school / MA. The material in the student book is formulated in the form of problems that will be solved by students or activities that are done individually or in groups with the guidance of the teacher. Problems that are appropriate for daily life will be able to develop creativity in solving students' problems. The development of this student book considers the learning model used in the study, the Novick learning model.

3) Student Worksheet

The selection of learning material should be guided by the understanding that the learning material provides activities that are student-centered. So student worksheet system of three-variable linear equations designed contains questions that invite students to think systematically to solve a problem related to daily life.

4) Learning Outcomes Test

The THB design of the three-variable linear equation system developed refers to the indicators of achievement of system competencies in three-variable linear equations with problem-based models.

c. Development Stage (Develop)

This stage aims to produce prototypes of learning devices based on conceptual conflict models in solving mathematical problems that have been validated by experts and practitioners and revised so that they are suitable for use in the learning process.

1) Analysis of the Results of Validity Data on Problem Based Learning Devices Based on validation I and II and the validator's comments on the feasibility of problem-based mathematics learning devices summarized as follows in table 1 and table 2. 
Tabel 1. Suggestions for the Improvement of Prototype I by Validator

\begin{tabular}{ll}
\hline \multicolumn{1}{c}{ Aspect } & \multicolumn{1}{c}{ Recommendation for Improvement } \\
\hline Lesson Plan & $\begin{array}{l}\text { Adjust the learning model that will lead to conceptual } \\
\text { conflict } \\
\text { The step of learning is more operational }\end{array}$ \\
\hline Student Book & $\begin{array}{l}\text { 1. The concept and procedure for writing should be } \\
\text { considered }\end{array}$ \\
& $\begin{array}{l}\text { 2. All images must be equipped with the source. It is better } \\
\text { that problems presented in the book of the students is a } \\
\text { matter of everyday life in accordance with the intelligence } \\
\text { of learners }\end{array}$ \\
\hline Student Worksheet & $\begin{array}{l}\text { 1. Clarify the picture on the LKPD } \\
\text { 2. Clarify the question and the LKPD as short as possible in } \\
\text { the form of information or illustrations and questions }\end{array}$ \\
\hline Learning Outcome & $\begin{array}{l}\text { 1. Clarify the question grid } \\
\text { 2. Adjust the problem with the learning model used }\end{array}$ \\
& $\begin{array}{l}\text { 3. Adjust the problem with the indicators you want to } \\
\text { achieve }\end{array}$ \\
\hline Implementation & $\begin{array}{l}\text { The activities of students who come out of the learning } \\
\text { process need to be considered, therefore there needs to } \\
\text { be more attention from the teacher }\end{array}$ \\
\hline
\end{tabular}

Tabel 2. Suggestions for Improving the Prototype II by Validator

\begin{tabular}{|c|c|}
\hline Aspect & Recommendation for Improvement \\
\hline Lesson Plan & $\begin{array}{l}\text { 1. The learning model is appropriate for generating } \\
\text { conceptual conflict } \\
\text { 2. The learning step is operational }\end{array}$ \\
\hline Student Book & $\begin{array}{l}\text { 1. The concepts and procedures for writing are good } \\
\text { 2. All images have the source } \\
\text { 3. Problems that are presented in the student's book are } \\
\text { problems of daily life in accordance with the catchment of } \\
\text { students }\end{array}$ \\
\hline $\begin{array}{l}\text { Student } \\
\text { Woorksheet }\end{array}$ & $\begin{array}{l}\text { 1. The picture on the LKPD has been clarified } \\
\text { 2. Questions on LKPD are simple and clear }\end{array}$ \\
\hline Learning Outcome & 1. The question grid is clear \\
\hline Test & $\begin{array}{l}\text { 2. The question is in accordance with the learning model } \\
\text { used } \\
\text { 3. The question is in accordance with the indicators to be } \\
\text { achieved }\end{array}$ \\
\hline Implementation & There are already concerns for students \\
\hline
\end{tabular}




\section{2) Analysis of Data Results in Practical Problem Based Learning Devices}

The main objective of the data analysis of the implementation of the devices resulting from the limited trials is to see the practicality of the device. However, to emphasize more on the implementation of the observation sheet of the device that is used to fulfill reliability empirically, then the calculation of the reliability of the instrument is based on the data from the limited trial results. If the results of reliability calculations conclude that the instrument is not reliable, then the data from the limited trial results are not feasible to use to assess the practicality of the learning device. In order to more easily draw conclusions, the observation data for device implementation is analyzed per component. The results of the analysis for each component are explained below.

3) Analysis of Data Results of the Effectiveness of Learning Devices

In the results of students 'responses, students' responses to learning devices are divided into 2 aspects, namely: (1) students 'responses to student books, and (2) students' responses to the student worksheet. Based on the results of the analysis of students' responses to student books in limited trials, there were $85 \%$ of students who responded positively to student books, and $92.5 \%$ of students responded positively to student worksheet, in limited trials students responded positively to learning device.

In the test of learning outcomes of students, to assess the learning outcomes of students in learning used mastery test materials. Based on the data analysis of student learning outcomes in a limited trial in terms of completeness there are 30 students from 35 people (85\%) students who score 6.5 and above. Thus the learning outcomes of students are as expected.

On the student activity sheet. Based on the results of the analysis of student activity data in a limited trial, five of the six types of student activities observed were met. Thus according to the activity criteria students are expected to have reached a limited trial.

\section{Discussion}

a. The Defining Stage of Conteptual-Conflict-Based Learning Device in Mathematical Problem Solving

At the defining stage it aims to determine the basic problems needed to develop learning devices. At this stage, there were still many students in class $X$ MIA MAN 1 Makassar whose mastery of mathematical concepts was still very low. One of the weaknesses of the students is that they have not been able to 
solve the story questions that are required to master good concepts and good principles and skills.

b. The Designing Phase of Conteptual-Conflict-Based Learning Device in Mathematical Problem Solving

At this stage the Lesson Plan, Student Books, Student Worksheets, and Learning Outcomes Test are produced as a solution to the definition phase. The result of the draft of Lesson Plan follows the 2013 curriculum format while the design of the Student Book and Student Worksheet follow the needs of the students in class $\mathrm{X}$ at MIA MAN 1 Makassar.

The design of the development of conteptual-conflict-based learning device in mathematical problem solving on the subject of three-variable linear equations is intended to make it easier for students to learn mathematics, especially how to identify a problem, then develop a plan for solving and implementing the solution plan. It starts from recognizing a system of threevariable linear equations, completing the SPLTV set, recognizing a system of three-variable linear equations, completing a system of three-variable linear equations, making a model of a three-variable linear equation system and solving it.

c. Stage of Development of Conteptual-Conflict-Based Learning Device in Mathematical Problem Solving

At this stage a prototype is created, the main design based on the initial design. The prototype made are Lesson Plan, Student Book, Student Worksheet, and Learning Outcome Test. In the first validation of prototype I conteptualconflict-based learning device in mathematical problem solving were validated by experts and practitioners and were given input to improve the device. The validation results in the first stage have not been declared valid so that revisions still need to be made based on input from the validators and produced prototypes II, then the second stage of validation is carried out which is then declared valid and feasible to use.

In general, it can be said that the learning device developed in this study are learning implementation plans, student books, student activity sheets, and learning outcomes tests can provide a new atmosphere. The following are the differences between student book, student worksheet and the learning outcomes test used by the teacher and those that have been developed, namely: 


\section{1) Student Book}

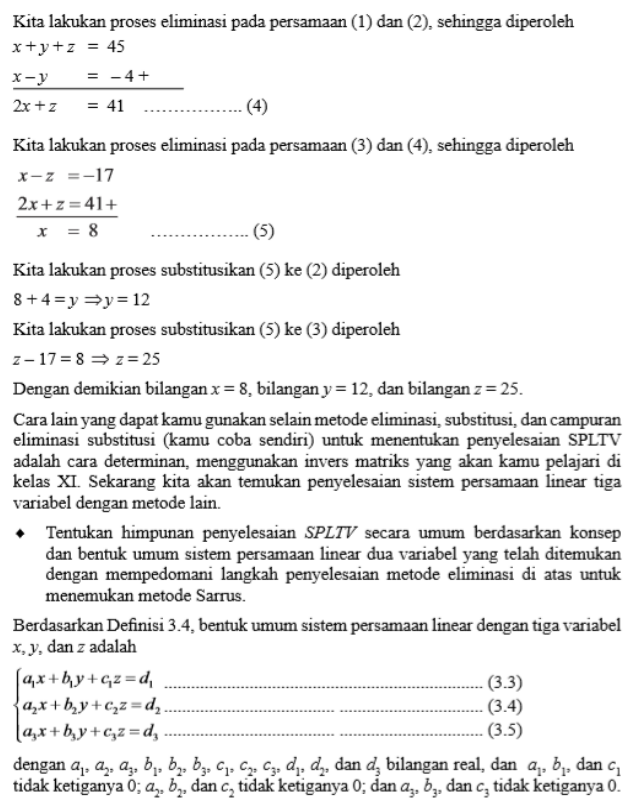

- Tentukan himpunan penyelesaian SPLTV secara umum berdasarkan konsep dan bentuk umum sistem persamaan linear dua variabel yang telah ditemuka engan mempedomani langkah penyelesaian metode eliminasi di atas untuk menemukan metode Sarrus.

Berdasarkan Definisi 3.4, bentuk umum sistem persamaan linear dengan tiga variabel $x, y$, dan $z$ adalah

$\left(a_{1} x+b_{1} y+c_{1} z=d_{1}\right.$

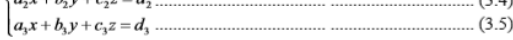

dengan $a_{1}, a_{2}, a_{3}, b_{1}, b_{2}, b_{3}, c_{1}, c_{2}, c_{3}, d_{1}, d_{2}$, dan $d_{3}$ bilangan real, dan $a_{1}, b_{1}$, dan $c_{1}$ tidak ketiganya $0 ; a_{2}, b_{2}$, dan $c_{2}$ tidak ketiganya 0 ; dan $a_{3}$, $b_{3}$, dan $c_{3}$, tidak ketiganya 0 .

(a)
Pengertian Sistem Persomaen Linear Tiga Variabel (SPLTV)

Rechatikan masalab kegiatan inal beli berikut in:

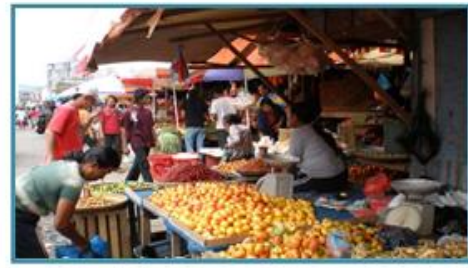

Ihu Ani berujung ke 2959r seagr di kota Makassar. Ja membeli tigs ienis bushkushan xaitu buah apel. bush jeruk dan bush semangks. Jikg ia membeli $5 \mathrm{~kg}$

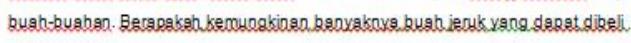
IRuAai?

Pechatikan masalah di atgs kemudian jawablgh petanyasn-pertanyasn berikut!

1. Bustlah Remisalan dari massalah tersebut!

2. Tulikkan Rersamagn linear tigs variabel dad masalah tersebut

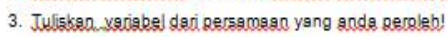

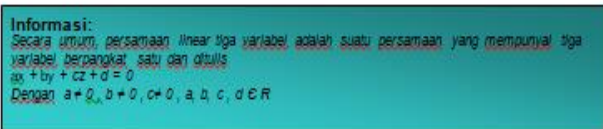

\section{sakn arsis}

(b)

Picture 2. Display of Books of Students Used by Teachers (a) and Developed (b)

2) Student Worksheet

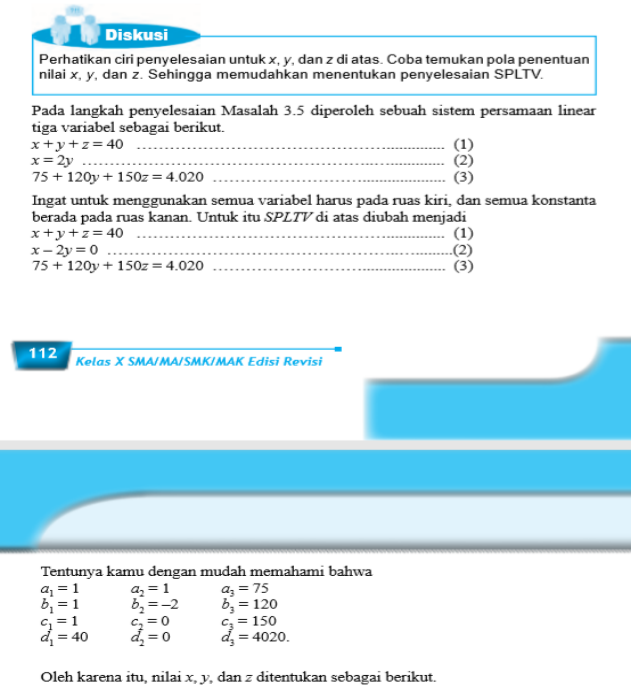

(a)

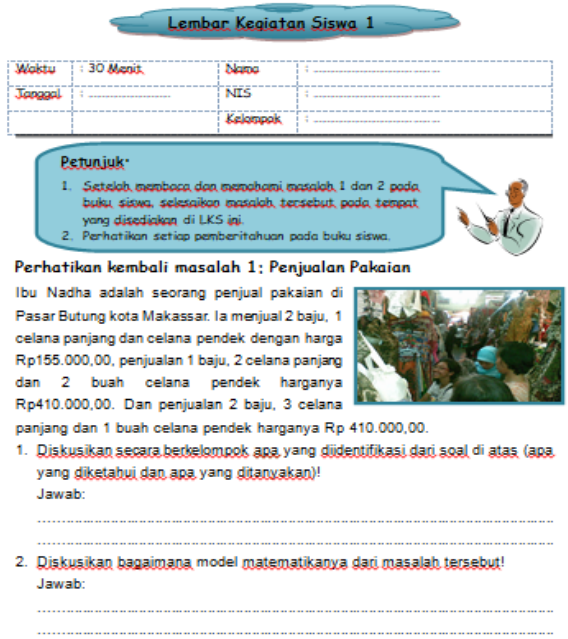

(b)

Picture 3. Display of LKPD used by teachers (a) and Developed (b) 
2. Learning Outcomes Test (THB)

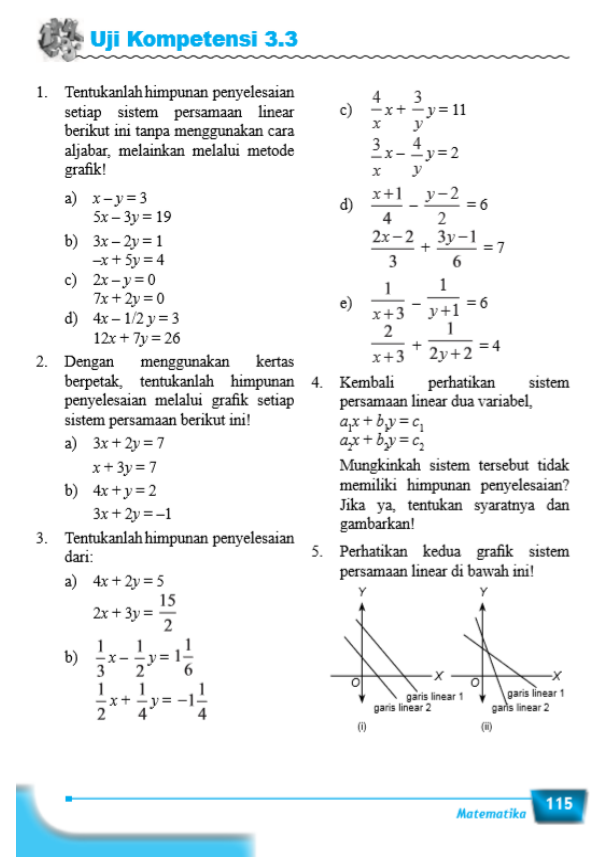

(a)

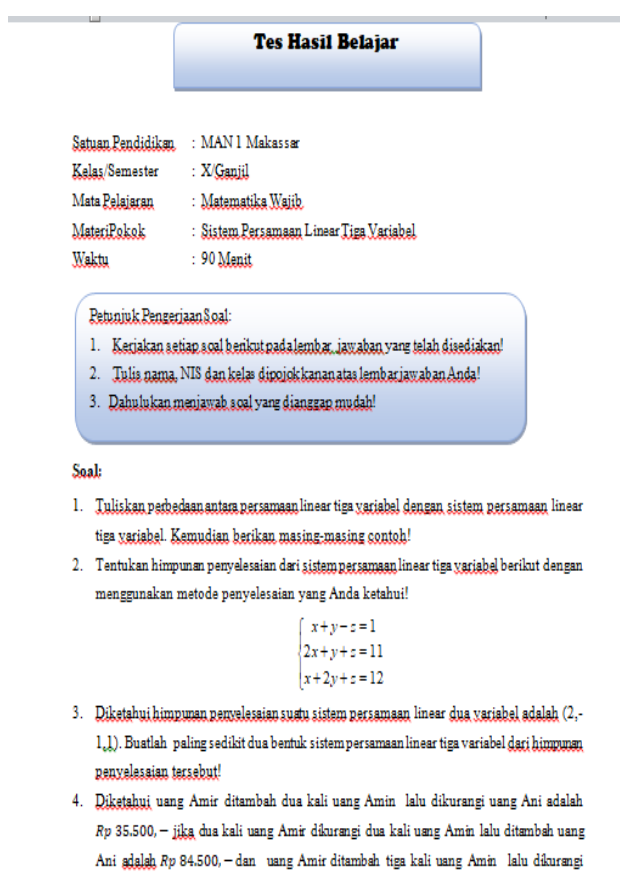

(b)

Picture 4. THB Display used by Teacher (a) and Developed (b)

\section{Stage Conteptual-Conflict-Based Learning Device in Mathematical Problem Solving}

After mathematical learning device based on conceptual conflict in mathematical problem solving on the subject of the three variable linear equations are developed and declared valid and the results of limited and field trials meet the eligibility requirements, it can be concluded that problem-based mathematics learning device which is developed practically and effectively used to develop students' mathematical abilities in problem solving based on conceptual conflict.

\section{CONCLUSION}

Learning device that have been developed have met 3 eligibility requirements, namely valid, practical, and effective. In terms of validity, based on the results of the learning device validation, the data obtained that the validation results are divided into two stages, namely the validation stage I and the validation stage II. At the stage of validation I, all learning devices are said to be invalid and not suitable for use. In stage II all the suggestions from the 
validator have been corrected and are said to be valid and appropriate to use. In terms of practicality, based on the results of practical testing, it can be said that the learning device is practical based on the results of the implementation. While in terms of effectiveness, based on the results of the trial data obtained effectiveness data that: (1) the average mastery learning obtained by students is $85 \%$. (2) five of the six types of student activities observed have been fulfilled. and (3) and the results of students' responses to learning is positive with $85 \%$ of students responding positively to student books and $92.5 \%$ of students responding positively to student worksheet. So, it can be concluded that the learning device is effective to be use.

\section{REFERENCES}

Abdurrahman, M. (2009). Pendidikan bagi anak berkesulitan belajar. Jakarta: Rineka Cipta.

Abrar, A. I. P. (2016). Pembelajaran berdasarkan masalah suatu upaya untuk mengembangkan kemampuan pemahaman dan representasi matematika. MaPan: Jurnal Matematika dan Pembelajaran, 4(1), 1-10. Retrieved from http:// portalriset.uinalauddin.ac.id/bo/upload/penelitian/penerbitan_jurnal/1 - Andi Ika Prasasti (1-10) FIX.pdf

Angriani, A. D., \& Bernard, Nur, R. N. (2016). Meningkatkan kemampuan pemecahan masalah melalui pembelajaran kooperatif think-talk-write pada peserta didik kelas viiil mtsn model makassar. MaPan: Jurnal Matematika Dan Pembelajaran, 4(1), 11-28. Retrieved from http://journal.uin-alauddin.ac.id/index.php/Mapan/article/view/2796

Asdar. (2012). Pemanfaatan strategi konflik kognitif dalam pemecahan masalah matematika untuk memperkuat pemahaman konsep geometri siswa sma di kota makassar. Makassar: Universitas Negeri Makassar.

Asdar. (2015). Assesmen otentik dalam pembelajaran matematika model koncama. Makassar.

Kemendiknas. (2013). Permendiknas nomor 70 tahun 2013 tentang kerangka dasar dan struktur kurikulum sekolah menengah kejuruan/madrasah aliyah kejuruan. Jakarta: BSNP.

Lahinda, Y., \& Jailani. (2015). Analisis proses pemecahan masalah matematika siswa Sekolah Menengah Pertama. Jurnal Riset Pendidikan Matematika, 2(1), 148-161. Retrieved from https://journal.uny.ac.id/index.php/jrpm/article/view/7157

Lee, Gyoungho., et. al. (2003). Developmen of an instrument for measuring cognitive conflict in secondary-level sciences classes. Research in Science Teaching, 40(6), 585-603. Retrieved from www.pre.aegean.gr/lab$\mathrm{fe} /$ downloads/articles/cognitive_conflict.pdf $\% 0 \mathrm{~A} \% 0 \mathrm{~A}$ 
Liang, S. (2016). Teaching the concept of limit by using conceptual conflict strategy and desmos graphing calculato. International Journal of Research in Education and Science (IJRES), 2(1), 35-48. Retrieved from https://www.ijres.net/index.php/ijres/article/view/84\%0A\%0A

Piaget, J. (1985). The equilibration of cognitive structure: The central problem of intellectual development. Chicago: The University of Chicago Press.

Polya, G. (1973). How to solve it (a new aspect of mathematical method), Second Edition. Pricenton University Press.

Sela, H., \& Zaslavsky, O. (2007). Resolving cognititive conflict with peers - is there a difference between two and four? In Proceeding of the 31st Conference Of International Group for the Psychology of Mathematics Education. seoul.

Sutrisman, \& Tambunan., G. (1987). Pengajaran matematika. Jakarta: Karunika Universitas Terbuka.

Wahyuni, F. (2017). Pengembangan perangkat pembelajaran berbasis model pembelajaran berdasarkan masalah untuk meningkatkan kemampuan pemecahan masalah matematik Siswa SMP Negeri 3 Sunggal. Journal of Mathematics Education and Science, 2(2), 17-29. Retrieved from https://jurnal.uisu.ac.id/index.php/mesuisu/article/view/127 